\title{
Corrigendum
}

\section{Corrigendum to "Safety and Clinical Usage of Newcastle Disease Virus in Cancer Therapy"}

\author{
Han Yuen Lam, ${ }^{1}$ Swee Keong Yeap, ${ }^{2}$ Mehdi R. Pirozyan, ${ }^{2}$ Abdul Rahman Omar, \\ Khatijah Yusoff, ${ }^{3}$ Suraini Abd-Aziz, ${ }^{4}$ and Noorjahan Banu Alitheen ${ }^{1}$ \\ ${ }^{1}$ Department of Cell and Molecular Biology, Faculty of Biotechnology and Biomolecular Sciences, Universiti Putra Malaysia, \\ 43400 Serdang, Selangor, Malaysia \\ ${ }^{2}$ Institute of Bioscience, Universiti Putra Malaysia, 43400 Serdang, Selangor, Malaysia \\ ${ }^{3}$ Department of Microbiology, Faculty of Biotechnology and Biomolecular Sciences, Universiti Putra Malaysia, \\ 43400 Serdang, Selangor, Malaysia \\ ${ }^{4}$ Department of Bioprocess Technology, Faculty of Biotechnology and Biomolecular Sciences, Universiti Putra Malaysia, \\ 43400 Serdang, Selangor, Malaysia
}

Correspondence should be addressed to Noorjahan Banu Alitheen; noorjahan@upm.edu.my

Received 2 November 2016; Accepted 25 September 2017; Published 3 December 2017

Copyright (C) 2017 Han Yuen Lam et al. This is an open access article distributed under the Creative Commons Attribution License, which permits unrestricted use, distribution, and reproduction in any medium, provided the original work is properly cited.

In the article titled "Safety and Clinical Usage of Newcastle Disease Virus in Cancer Therapy" [1] the name of the third author was given incorrectly as Mehdi Rasoli. The author's name should have been written as Mehdi R. Pirozyan. In addition, the first and last names of the sixth author were reversed. The revised authors' list is shown above.

\section{References}

[1] H. Y. Lam, S. K. Yeap, M. Rasoli et al., "Safety and clinical usage of newcastle disease virus in cancer therapy," Journal of Biomedicine and Biotechnology, vol. 2011, Article ID 718710, 2011. 


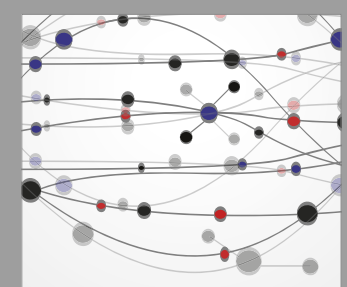

The Scientific World Journal
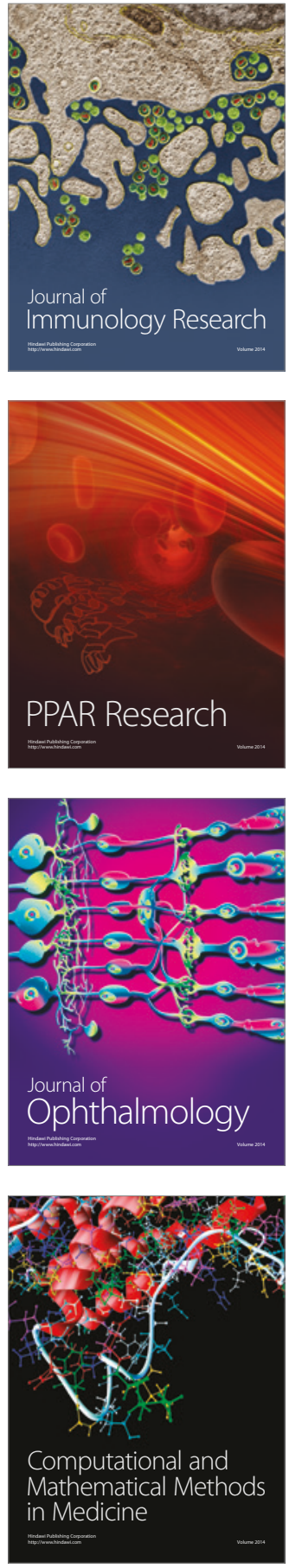

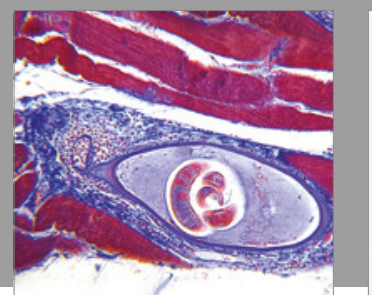

Gastroenterology Research and Practice
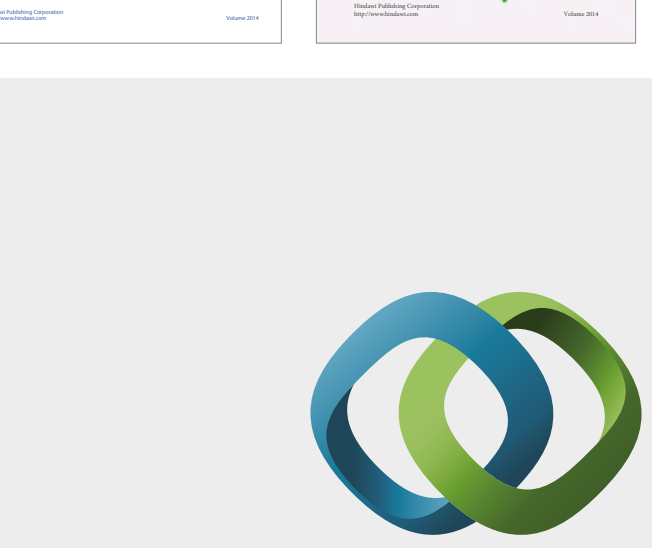

\section{Hindawi}

Submit your manuscripts at

https://www.hindawi.com
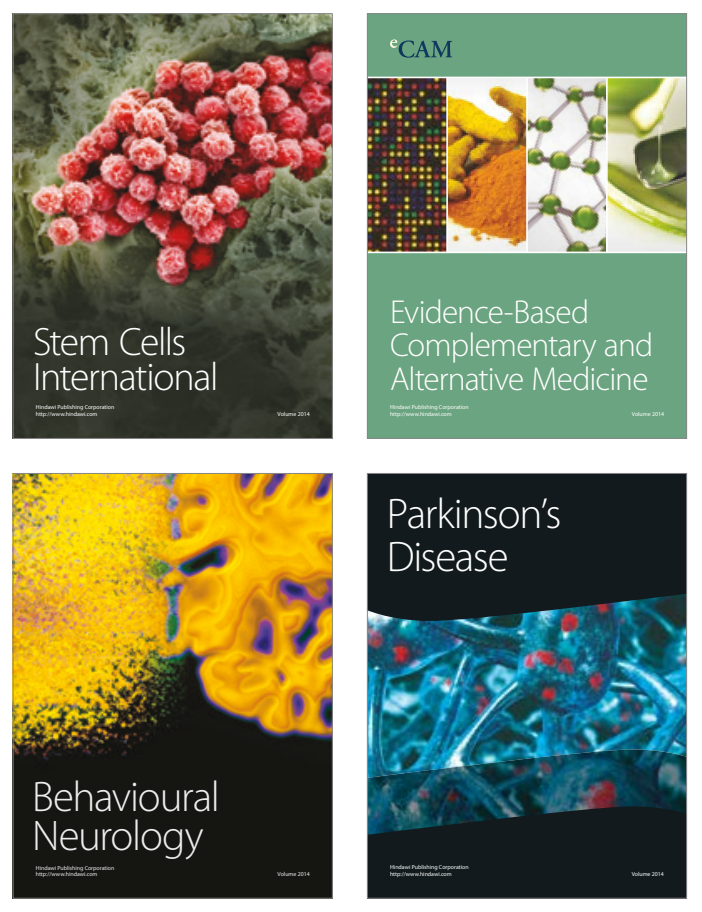
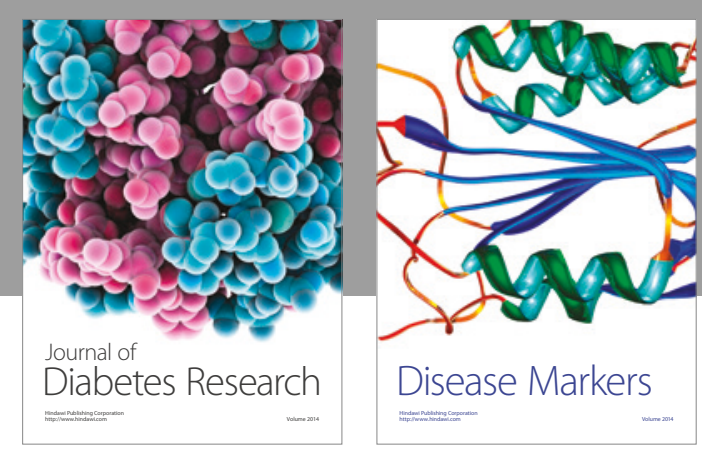

Disease Markers
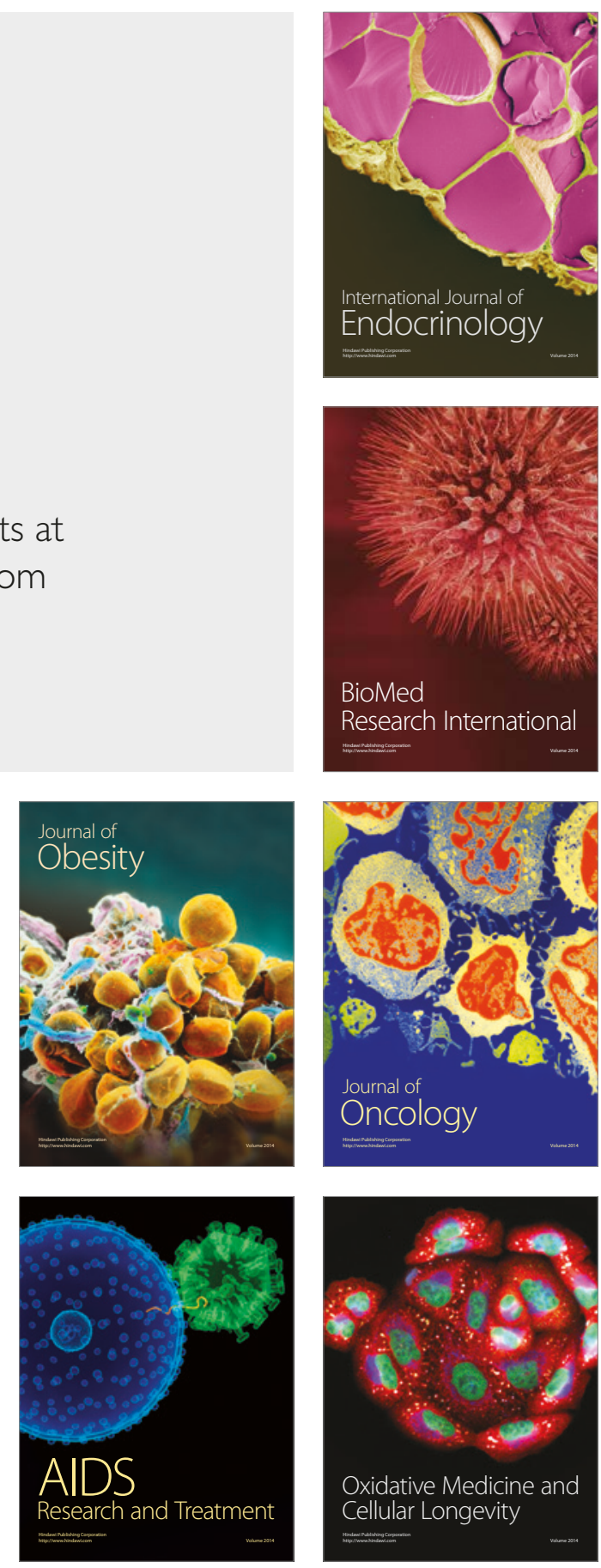